\title{
New records of Helminths in Reptiles from five states of Brazil
}

\author{
T. F. Quirino $a^{*}$, A. J. M. G. Ferreira ${ }^{b}$, M. C. Silva ${ }^{a}$, R. J. Silva ${ }^{c}$, D. H. Morais ${ }^{a}$ and R. W. Ávila \\ aPrograma de Pós-graduação em Bioprospecção Molecular, Departamento de Química Biológica, \\ Universidade Regional do Cariri - URCA, Rua Cel. Antônio Luiz, 1161, Campus do Pimenta, \\ CEP 63105-000, Crato, CE, Brazil \\ ${ }^{\mathrm{b}}$ Laboratório de Herpetologia, Departamento de Química Biológica, Universidade Regional do Cariri - URCA, \\ Rua Cel. Antonio Luiz, 1161, Bairro do Pimenta, CEP 63105-100, Crato, CE, Brazil \\ 'Departamento de Parasitologia, Instituto de Biociências, Universidade Estadual Paulista - UNESP, \\ Campus de Botucatu, Avenida Bento Lopes, s/n, Distrito de Rubião Junior, CEP 18080-970, Botucatu, SP, Brazil \\ *e-mail: tata_tatifeitosa@hotmail.com
}

Received: March 12, 2017 - Accepted: May 18, 2017 - Distributed: November 30, 2018

\begin{abstract}
Forty five specimens representing nine species of reptile (Salvator merianae, Enyalius bilineatus, Amphisbaena alba, Xenopholis undulatus, Chironius fuscus, Helicops angulatus, Chironius flavolineatus, Erythrolamprus viridis and Crotalus durissus) collected in five Brazilian states were examined for helminths. Twelve helminth species were found as follow: nine Nematoda (Physaloptera tupinambae, Strongyluris oscari, Paracapillaria sp., Dracunculus brasiliensis, Physaloptera liophis, Serpentirhabias sp. 1, Serpentirhabias sp. 2, Serpentirhabias sp. 3 and Aplectana sp.), one Cestoda (Semenoviella amphisbaenia), one Trematoda (Paracotyletrema sp.), and one Acantocephala (Centrorhynchus sp.). Ten new host records and seven new locality records were reported.
\end{abstract}

Keywords: parasite, snakes, lizards, amphisbaenidae, nematoda.

\section{Novos registros de helmintos em répteis de cinco estados do Brasil}

\section{Resumo}

Quarenta e cinco espécimes que representa nove espécies de répteis (Salvator merianae, Enyalius bilineatus, Amphisbaena alba, Xenopholis undulatus, Chironius fuscus, Helicops angulatus, Chironius flavolineatus, Erythrolamprus viridis e Crotalus durissus) coletados em cinco estados brasileiros foram examinados para helmintos. Foram encontrados doze espécies de helmintos sendo: nove Nematoda (Physaloptera tupinambae, Strongyluris oscari, Paracapillaria sp., Dracunculus brasiliensis, Physaloptera liophis, Serpentirhabias sp. 1, Serpentirhabias sp. 2, Serpentirhabias sp. 3 e Aplectana sp.), um Cestoda (Semenoviella amphisbaenia), um Trematoda (Paracotyletrema sp.) e um Acantocephala (Centrorhynchus sp.). Dez novos registros de hospedeiros e sete novos registros de localidade foram relatados.

Palavras-chave: parasita, serpentes, lagartos, anfisbenídeos, nematoda.

\section{Introduction}

Surveys is one of the most suitable ways to expand knowledge on biodiversity and understand how the species, and what species, are parts of an ecosystem. Likewise, parasitological surveys are important for understanding parasite/host relationships, as well as ecological aspects and estimations on local biodiversity (Rocha et al., 2003; Marcogliese, 2005; Campião et al., 2015). Moreover, parasitism is a key feature in population dynamics and community structure (Ernst and Ernst, 1980).

Inventories of helminths from reptiles are relatively frequent and are very useful for filling the gaps in the ecological and taxonomic knowledge, for they enhance and constitute the development and the comprehension of the parasitism in the vertebrates (Muzzall, 2005;
Ávila and Silva, 2010; Ávila et al., 2010; Pereira et al., 2012; Albuquerque et al., 2013; Cabrera-Guzmán and Garrido-Olvera, 2014).

Studies focusing helminth parasites infecting squamate reptiles in Brazil have been increased in the past few years (Bursey et al., 2007; Ávila et al., 2010; Ávila et al., 2011; Barreto-Lima et al., 2012; Araujo-Filho et al., 2014; Mati et al., 2015). The information gathered was also compiled on extensive literature reviews, such as Ávila and Silva (2010) for helminths of lizards and amphisbaenians and Fernandes and Kohn (2014) for trematodes of reptiles.

Herein, we report the helminths infecting nine species of reptile in seven localities from Brazil, thereby increasing our knowledge of reptile's parasites in the Neotropical region. 


\section{Materials and Methods}

Reptiles were collected from 2002 to 2012 in five Brazilian states, Minas Gerais: Viçosa (2045'16.52'S; 42 52 '42.88”O) and Florestal (1953'18.68's; 44²5'55.63”O) municipalities, Mato Grosso: Aripuanã (10¹0'35"'S; 59²6’52.42”O) municipality, Ceará: Várzea Alegre (647’39.68'S; 39¹7’35.56”O), Farias Brito (655’34.10”S; 39॰34'23.83'O), and Aiuaba (6³3'54.38'S; 40¹3'37.65”O) municipalities, Pernambuco: Exú (7²6’14.56"S; 39 44'03.62'O) municipality and São Paulo: Botucatu (233'17.56”S; 48³1'10.24”O) municipality. Voucher specimens were housed in the Herpetological collections of the Universidade Federal de Minas Gerais (UFMG) and Museu de Zoologia da Universidade Federal de Viçosa (MZUFV), in Minas Gerais state, at the Coleção Zoológica de Vertebrados da Universidade Federal de Mato Grosso (UFMT) in Mato Grosso state, at the Coleção Zoológica da Universidade Regional do Cariri (URCA), in Ceará state.

Specimens were caught by hand or by pitfall-traps, euthanized, fixed in 10\% formalin, and preserved in 70\% ethanol. For each specimen, snout-vent length (SVL) was measured using a digital caliper $(0.01 \mathrm{~mm}$ precision $)$. The specimen o Chironius flavolineatus and Crotalus durissus were discarded due tostage of decomposition. Sex of the hosts was determined by direct inspection of gonads or presence/absence of hemipenes. The body cavity of all specimens other than those from Minas Gerais and São Paulo was opened by a longitudinal incision from throat to vent, the gastrointestinal tract was slit longitudinally, and the body cavity, lungs, gall bladder, lungs, stomach, and intestinal contents were removed and examined under a stereomicroscope. For specimens from Minas Gerais state, parasites were collected during examination of gut content from three tegu lizards (Salvator merianae, Duméril and Bibron, 1839), and during formalin injection in one lizard (Enyalius bilineatus, Duméril and Bibron, 1837), one amphisbaenian (Amphisbaena alba, Linnaeus, 1758), and one snake (Xenopholis undulates, Jensen, 1900). Helminths found in the gastrointestinal tract, lungs, or body cavity were placed in vials of $70 \%$ ethanol for later identification. For species identification, nematodes were cleared in phenol and acanthocephalans, trematodes, and cestodes were stained in carmine and cleared with creosote. All helminthes were analyzed using image analysis software (Qwin Lite 3.1, Leica Microsystems, Wetzlar, Germany). Voucher helminth specimens were deposited in the Coleção Helmintológica do Instituto de Biociências da Unesp de Botucatu (CHIBB) and Coleção Parasitológica da Universidade Regional do Cariri (URCA - P).

\section{Results}

A total of 45 specimens belonging to nine species of reptile were collected. Nineteen specimens were infected with at last one helminth species: Salvator merianae $(\mathrm{N}=3, \mathrm{SVL}=302.5 \pm 84.6 \mathrm{~mm})$, Enyalius bilineatus $(\mathrm{N}=1, \mathrm{SVL}=82 \mathrm{~mm})$, Amphisbaena alba $(\mathrm{N}=1, \mathrm{SVL}=480 \mathrm{~mm})$, Xenopholis undulatus $(\mathrm{N}=1$, $\mathrm{SVL}=3950 \mathrm{~mm})$, Chironius fuscus, Linnaeus, 1758 $(\mathrm{N}=1, \mathrm{SVL}=771 \mathrm{~mm})$, Helicops angulatus, Linnaeus, $1758(\mathrm{~N}=16, \mathrm{SVL}=423 \pm 201 \mathrm{~mm})$, Erythrolamprus viridis, Günther, $1862(\mathrm{~N}=10, \mathrm{SVL}=425 \pm 230 \mathrm{~mm})$, Chironius flavolineatus, Jan, $1873(\mathrm{~N}=1)$ Crotalus durissus, Laurenti, $1768(\mathrm{~N}=1)$. Two hundred and seventy two helminths belonging to 12 species were recovered (Table 1).

Table 1. Results containing the species, locality and number of species (n), Helminths, prevalence (P), distribuition and Site of Infection (S.Inf.): Stomach (S), intestines (I), Large intestine (LI), Small intestines (SI), Buccal cavity (BC), Coelomic cavity (CC), Lung (L) and Body cavity (BoC).

\begin{tabular}{|c|c|c|c|c|c|}
\hline Species & Locality (n) & Helminths & $\mathbf{P}$ & Distribution & S.Inf. \\
\hline Salvator merianae & Viçosa-MG (3) & Physaloptera tupinambae & 175 & $\begin{array}{c}\text { October } 2002, \\
\text { October and } \\
\text { November } 2008\end{array}$ & $\mathrm{~S} / \mathrm{I}$ \\
\hline Enyalius bilineatus & Viçosa-MG (1) & Strongyluris oscari & 16 & November 2008 & LI \\
\hline Amphisbaena alba & Viçosa-MG (1) & Semenoviella amphisbaenae & 26 & February 2009 & SI \\
\hline Chironius fuscus & Aripuanã-MG (1) & Paracotyletrema sp. & 1 & October 2007 & $\mathrm{BC}$ \\
\hline Chironius flavolineatus & Botucatu-SP (1) & Serpentirhabdias sp. 1 & 3 & May 2015 & $\mathrm{~L}$ \\
\hline Xenopholis undulatus & Florestal-MG (1) & Serpentirhabdias sp. 2 & 13 & October 2012 & $\mathrm{~L}$ \\
\hline \multirow[t]{3}{*}{ Helicops angulatus } & Aripuanã-MG (3) & Paracapillaria sp. & 5 & October 2007 & $\mathrm{CC}$ \\
\hline & & Paracotyletrema sp. & 2 & October 2007 & $\mathrm{BC}$ \\
\hline & & Dracunculus brasiliensis & 1 & January 2008 & $\mathrm{CC}$ \\
\hline \multirow[t]{3}{*}{ Erythrolamprus viridis } & $\begin{array}{c}\text { Várzea Alegre-CE (6) } \\
\text { and Aiuaba-CE (1) }\end{array}$ & Centrorhynchus sp. & 10 & $\begin{array}{c}\text { October } 2011 \text { and } \\
\text { May } 2012\end{array}$ & $\mathrm{BoC}$ \\
\hline & & Physaloptera liophis & 8 & $\begin{array}{l}\text { October 2011, } \\
\text { May and June } \\
2012\end{array}$ & $\mathrm{~S}$ \\
\hline & & Aplectana sp. & 2 & $\begin{array}{c}\text { October } 2011 \text { and } \\
\text { May } 2012\end{array}$ & LI \\
\hline Crotalus durissus & Botucatu-SP (1) & Serpentirhabdias sp. 3 & 10 & May 2016 & $\mathrm{~L}$ \\
\hline
\end{tabular}




\section{Discussion}

Our study, 10 new host and 7 new locality records are provided. Paracapillaria, Dracunculus and Physaloptera are considered generalists, being frequently reported infecting amphibians and reptiles (Torres and Puga, 1996; Timi et al., 2007; Moravec and Santos, 2009; Pereira et al., 2012).

Nematodes of the genus Paracapillaria are known to use fishes as intermediate hosts (Gibbons, 2010), being reported infecting 39 fish species (De and Maity, 1994; Moravec et al., 1996; Timi et al., 2007), two amphibians (Goldberg and Bursey, 2002; Moravec et al., 2007), and 10 species of reptile (Vicente et al., 1993; De, 1998; Goldberg et al., 2004; Moravec and Gibson, 2007). Helicops angulatus and Mato Grosso state is a new host and new locality record for the genus Paracapillaria.

Dracunculus brasiliensis (Moravec and Santos, 2009) was described infecting the green anaconda Eunectes murinus, being the only species of Dracunculus reported in South American reptiles (Moravec and Santos, 2009). Helicops angulatus and Mato Grosso state is a new host and new locality record for the D. brasiliensis.

Physaloptera liophis (Vicente and Santos, 1974) was described in the stomach of Liophis miliaris from Brazil (Vicente and Santos, 1974) and latter recorded infecting Bothrops neuwiedi at the municipality of Ingaí, Minas Gerais state, Brazil (Gouveia et al., 2012). Erythrolamprus viridis and Ceará state is a new host and new locality record for P. liophis. Physaloptera tupinambae (Pereira et al., 2012) can be distinguished from the other Neotropical species of Physaloptera by length of spicules and by possessing a bipartite internal tooth (Pereira et al., 2012).

Serpentirhabdias is specific of snakes (Tkach et al., 2014). The uncertain diagnostic value of various morphological characters has caused instability in the determination of species (Kuzmin et al., 2007; Tkach et al., 2014), but the presence or absence of various structures at the anterior end, as well as their variations in shape and position have been widely used for species differentiation this genus (Tkach et al., 2014). The distinctive shape of the frontal end, morphometric and morphological characters in this sample presented did not allow the comparative diagnosis with any of the described species of the genus. Some specimens found may represent new species; unfortunately, the poor condition or absence of males in the samples makes difficult their identification. This may be the case of Paracotyletrema, since only one species have been described from Uruguay (Volonterio et al., 2006). The genus is a new host record for Chironius fuscus and Helicops angulatus and new locality for Mato Grosso state.

Cistacanths of Centrorhynchus sp. have been reported infecting the intestine several amphibian and reptile hosts, they are paratenic host to bridge ecological gaps, because utilize arthropods as intermediate hosts, where larval development occurs. (Santos and Amato, 2010; Ávila and Silva, 2010). Erythrolamprus viridis and Ceará state is a new host and new locality record for the genus Centrorhynchus.
Aplectana is commonly found infecting amphibians and reptiles and actually comprises 51 species. Identification relies mainly on male characteristics such as spicule length and caudal papillae pattern (Sou and Nandi, 2015), and as we found only females the specific identity could not be assigned. Erythrolamprus viridis is a new host record for the genus Aplectana.

Semenoviella is a monotypic genus distinguished from Oochoristica by few characters, such as cirrus sac length and presence of vaginal sphincter (Rego, 1967). Minas Gerais state is a new locality record for $S$. amphisbaenae (Rudolphi, 1819).

In the past few years, many parasitological studies focusing Brazilian reptiles have been published (Araujo-Filho et al., 2014; Barreto-Lima and Anjos, 2014; Mati et al., 2015). However, 773 species of reptile species are currently recognized in Brazil (Costa and Bernils, 2015) and less than $30 \%$ were sampled for helminths. however, some species of snakes of parasites were only been described in recent years (Kuzmin et al., 2014, 2016) especially with inclusion of molecular data (Morais et al., 2016).

Thus, the data presented increases knowledge on the occurrence of species of parasites, their relations with the hosts, helping in knowledge related to the pattern of distribution of the species and here increase our knowledge about the helminth fauna associated with Brazilian reptiles.

\section{Acknowledgements}

We are grateful to the Coordenação de Aperfeiçoamento de Pessoal de Nível Superior (CAPES) for granting master's scholarships to Tatiana Feitosa Quirino and for a research fellowship (CAPES/PNPD) to Drausio Honório Morais. Robson Waldemar Ávila thanks Conselho Nacional de Desenvolvimento Científico e Tecnológico (CNPq) for providing a research fellowship (\#303622/2015-6). To Henrique C. Costa for sending helminths from Universidade Federal de Minas Gerais and for the valuable comments on the manuscript. To Instituto Chico Mendes de Conservação da Biodiversidade (ICMBio) for collecting permits.

\section{References}

ALBUQUERQUE, R.L., LARANJEIRAS, D.O., PROTÁZIO, A.S., SANTANA, D.J., RODRIGUES, R., MESQUITA, D.O. and FRANÇA, F.G.R., 2013 [viewed 2017 March 12]. Helicops angulatus (Watersnake). Diet. Herpetological Review, vol. 44, no. 3, pp. 522-523. Available from: https://ssarherps.org/ herpetological-review-pdfs/

ARAUJO-FILHO, J.A., RIBEIRO, S.C., BRITO, S.V., TELES, D.A., SOUSA, J.G.G., ÁVILA, R.W. and ALMEIDA, W.O., 2014. Parasitic nematodes of Polychrus acutirostris (Polychrotidae) in the Caatinga biome, Northeastern Brazil. Brazilian Journal of Biology $=$ Revista Brasileira de Biologia, vol. 74, no. 4, pp. 939942. PMid:25627606. http://dx.doi.org/10.1590/1519-6984.01313.

ÁVILA, R.W. and SILVA, R.J. 2010. Checklist of helminths from lizards and amphisbaenians (Reptilia, Squamata) of South America. Journal of Venomous Animals and Toxins including 
Tropical Diseaes, vol. 16, no. 4, pp. 543-572. http://dx.doi. org/10.1590/S1678-91992010000400005.

ÁVILA, R.W., CARDOSO, M.W., ODA, F.H. and SILVA, R.J., 2011. Helminths from lizards (Reptilia: Squamata) at the Cerrado of Goiás State, Brazil. Comparative Parasitology, vol. 78, no. 1, pp. 120-128. http://dx.doi.org/10.1654/4472.1.

ÁVILA, R.W., STRÜSSMANN, C. and SILVA, R.J., 2010. A new species of Cosmocercoides (Nematoda: Cosmocercidae) from a Gymnophthalmid lizard of Western Brazil. The Journal of Parasitology, vol. 96, no. 3, pp. 558-560. http://dx.doi. org/10.1645/GE-2336.1.

BARRETO-LIMA, A.F. and ANJOS, L.A., 2014 [viewed 2017 March 12]. Occurrence of Strongyluris oscari (Nematoda; Heterakidae) in Enyalius bilineatus (Squamata: Leiosaurinae) from the Brazilian Atlantic Forest. Herpetology Notes, vol. 7, pp. 455-456. Available from: http://hdl.handle.net/11449/137674.

BARRETO-LIMA, A.F., TOLEDO, G.M. and ANJOS, L.A., 2012. The nematode community in the Atlantic rainforest lizard Enyalius perditus Jackson, 1978 from south-eastern Brazil. Journal of Helminthology, vol. 86, no. 4, pp. 395-400. PMid:22008646. http://dx.doi.org/10.1017/S0022149X11000599.

BURSEY, C.R., GOLDBERG, S.R. and TELFORD-JUNIOR, S.R., 2007. Gastrointestinal helminths from 14 species of lizards from Panama with Descriptions of Five New Species. Comparative Parasitology, vol. 74, no. 1, pp. 108-140. http:// dx.doi.org/10.1654/4228.1.

CABRERA-GUZMÁN, E. and GARRIDO-OLVERA, L., 2014. Helminth parasites of the Lesser Scaly Anole, Anolis uniformis (Squamata: Dactyloidae), from Los Tuxtlas, Southern Mexico: evidence of diet and habitat use. South American Journal of Herpetology, vol. 9, no. 3, pp. 183-189. http://dx.doi.org/10.2994/ SAJH-D-14-00035.1.

CAMPIÃO, K.M., DE AQUINO, A.C., MORAIS, D.H., DA SILVA, R.J. and TAVARES, L.E.R., 2015. How many parasites species a frog might have? Determinants of parasite diversity in South American Anurans. PLoS One, vol. 10, no. 10, pp. e0140577. PMid:26473593. http://dx.doi.org/10.1371/journal.pone.0140577.

COSTA, H.C. and BÉRNILS, R.S., 2015 [viewed 2017 March 12]. Répteis brasileiros: lista de espécies 2015. Herpetologia Brasileira, vol. 4, no. 3, pp. 75-93. Available from: http://www. sbherpetologia.org.br/.

DE, N.C. and MAITY, R.N., 1994. Paracapillaria xenentodoni n. sp. (Nematoda: Trichuroidea) from the fish Xenentodon cancila (Hamilton) from West Bengal, India. Systematic Parasitology, vol. 27, no. 1, pp. 71-75. http://dx.doi.org/10.1007/BF02185668.

DE, N.C., 1998. Anew capillariid, Paracapillaria (Ophidiocapillaria) najae n. sp. (Nematoda: Trichuroidea), from an elapid snake in West Bengal, India. Systematic Parasitology, vol. 39, no. 2, pp. 153-157. http://dx.doi.org/10.1023/A:1005926412813.

ERNST, C.H. and ERNST, E.M., 1980. Relationships between North American turtles of the Chrysemys complex as indicated by their endoparasitic helminths. Proceedings of the Biological Society of Washington, vol. 93, no. 2, pp. 339-345.

FERNANDES, B.M.M. and KOHN, A., 2014. South American trematodes parasites of amphibians and reptiles. Rio de Janeiro: Fundação Oswaldo Cruz.

GIBBONS, L., 2010. Keys to the Nematode parasites of vertebrates. Parasites \& Vectors, vol. 3, no. 9, pp. 416. http:// dx.doi.org/10.1186/1756-3305-3-9.
GOLDBERG, S.R. and BURSEY, C.R., 2002. Helminths of ten Species of Anurans from Honshu Island, Japan. Comparative Parasitology, vol. 69, no. 2, pp. 162-176. http://dx.doi. org/10.1654/1525-2647(2002)069[0162:HOSOAF]2.0.CO;2.

GOLDBERG, S.R., BURSEY, C.R. and TELFORD-JUNIOR, S.R., 2004. Helminths of Six Species of Snakes from Honshu Island, Japan. Comparative Parasitology, vol. 71, no. 1, pp. 4960. http://dx.doi.org/10.1654/4084.

GOUVEIA, R.V., SILVA, D.A.N., NOVELLI, I.A. and VIEIRA, F.M., 2012 [viewed 2017 March 12]. Bothropoides neuwiedi (Neuwied's Lancehead). Endoparasites. Herpetological Review, vol. 43, no. 2, pp. 340. Available from: https://ssarherps.org/ herpetological-review-pdfs/.

KUZMIN, Y., GIESE, E.G., MELO, F.T.V., COSTA, P.A.F.B., MASCHIO, G.F. and SANTOS, J.N., 2016. Description of Serpentirhabdias atroxi n. sp. (Nematoda: Rhabdiasidae), a parasite of Brothrops atrox (Linnaeus) (Reptilia: Serpentes: Viperidae) in Brazilian Amazonia. Systematic Parasitology, vol. 93, no. 1, pp. 37-45. PMid:26739285. http://dx.doi.org/10.1007/ s11230-015-9603-y.

KUZMIN, Y., MELO, F.T.V. and SANTOS, J.N., 2014. A new species of Serpentirhabdias Tkach, Kuzmin \& Snyder, 2014 (Nematoda: Rhabdiasidae) parasitic in the brown ground snake Atractus major Boulenger (Reptilia: Serpentes: Dipsadidae) in Brazil. Systematic Parasitology, vol. 89, no. 2, pp. 101-106. PMid:25204597. http://dx.doi.org/10.1007/s11230-014-9520-5.

KUZMIN, Y., TKACH, V.V. and BROOKS, D.R., 2007. Rhabdias alabialis sp. nov. and $R$. pseudosphaerocephala sp. nov. (Nematoda: Rhabdiasidae) in the marine toad, Bufo marinus (Lissamphibia: Anura: Bufonidae) in Central America. The Journal of Parasitology, vol. 93, no. 1, pp. 159-165. PMid:17436957. http://dx.doi.org/10.1645/GE-858R.1.

MARCOGLIESE, D.J., 2005. Parasites of the superorganism: are they indicators of ecosystem health? International Journal for Parasitology, vol. 35, no. 7, pp. 705-716. PMid:15925594. http://dx.doi.org/10.1016/j.ijpara.2005.01.015.

MATI, V.L.T., PINTO, H.A. and MELO, A.L., 2015. Helminths of Liophis miliaris (Squamata, Dipsadidae): a list of species and new records. Helminthologia, vol. 52, no. 2, pp. 159-166. http:// dx.doi.org/10.1515/helmin-2015-0029.

MORAIS, D.H., AGUIAR, A., MÜLLER, M.I., NARCISO, R.B., SILVA, L.A.F. and SILVA, R.J., 2016. Morphometric and phylogenetic analyses of the Serpentirhabdias viperidicus $\mathrm{n}$. sp. (Nematoda: Rhabdiasidae) from the lancehead snake Bothrops moojeni Hoge, 1966 (Reptilia: Serpentes: Viperidae) in Brazil. Journal of Helminthology, vol. 91, no. 3, pp. 1-11. http://dx.doi. org/10.1017/S0022149X16000377. PMid:27346628.

MORAVEC, F. and GIBSON, D.I., 2007. The first record of Dracunculus mulbus (Nematoda: Dracunculidae) in the Papuan olive python Apodora papuana (Ophidia: Boidae). Helminthologia, vol. 44, no. 3, pp. 118-119. http://dx.doi.org/10.2478/s11687007-0017-5.

MORAVEC, F. and SANTOS, C.P., 2009. Dracunculus brasiliensis sp. n. (Nematoda: Dracunculidae) from the anaconda, Eunectes murinus (Ophidia: Boidae). Parasitology Research, vol. 104, no. 3, pp. 589-592. PMid:18975002. http://dx.doi.org/10.1007/ s00436-008-1234-7.

MORAVEC, F., MENDOZA-FRANCO, E. and VARGASVÁZQUEZ, J., 1996. Paracapillaria epinepheli $\mathrm{n}$. sp. (Nematoda: Capillariidae) from the red grouper Epinephelus morio (Pisces) 
from Mexico. Systematic Parasitology, vol. 33, no. 2, pp. 149153. http://dx.doi.org/10.1007/BF00009432.

MORAVEC, F., MODRY, D. and JIRKU, M., 2007. A new species of Paracapillaria (Nematoda: Capillariidae) from the intestine of the toad Duttaphrynus melanostictus (Anura) from the Malayan Peninsula. The Journal of Parasitology, vol. 93, no. 4, pp. 907-909. PMid:17918374. http://dx.doi.org/10.1645/ GE-1138R.1.

MUZZALL, P.M., 2005. Parasites of amphibians and reptiles from Michigan: a review of the literature 1916-2003. Ann Arbor: Michigan Department of Natural Resources. Fisheries Research Report, 2077.

PEREIRA, F.B., ALVES, P.V., ROCHA, B.M. and LIMA, S.S., 2012. A new Physaloptera (Nematoda: Physalopteridae) parasite of Tupinambis merianae (Squamata; Teiidae) from southeastern Brazil. The Journal of Parasitology, vol. 98, no. 6, pp. 1227-1235. PMid:22712869. http://dx.doi.org/10.1645/GE-3159.1.

REGO,A.A., 1967. Sobre alguns cestódeos parasitos de Répteis. Revista Brasileira de Biologia, vol. 27, no. 2, pp. 181-187.

ROCHA, C.F.D., VRCIBRADIC, D., VICENTE, J.J. and CUNHA-BARROS, M., 2003. Helminths infecting Mabuya dorsivittata (Lacertilia, Scincidae) from a high-altitude habitat in Itatiaia National Park, Rio de Janeiro State, southe as tern Brazil. Brazilian Journal of Biology $=$ Revista Brasileira de Biologia, vol. 63, no. 1, pp. 129-132. PMid:12914424. http:// dx.doi.org/10.1590/S1519-69842003000100017.

SANTOS, V.G.T.E. and AMATO, S.B., 2010 [viewed 2017 March 12]. Rhinella fernandezae (Anura, Bufonidae) a paratenic host of Centrorhynchus sp. (Acanthocephala, Centrorhynchidae) in Brazil. Revista Mexicana de Biodiversidad, vol. 81, no. 1, pp. 53-56. Available from: http://www.scielo.org.mx/pdf/rmbiodiv/ v81n1/v81n1a8.pdf.
SOU, S.K. and NANDI, A.P., 2015. On a new species of Cosmocerca (Nematoda: Cosmocercidae) from Microhyla rubra (Anura: Microhylidae) from West Bengal, India. Acta Parasitologica, vol. 60, no. 2, pp. 261-265. PMid:26203994. http://dx.doi.org/10.1515/ap-2015-0037.

TIMI, J.T., ROSSIN, M.A., LANFRANCHI, A.L. and ETCHEGOIN, J.A., 2007. A new species of Paracapillaria (Nematoda: Capillariidae) parasitizing the Brazilian Sandperch, Pinguipes brasilianus (Pisces: Pinguipedidae), from Argentina. The Journal of Parasitology, vol. 93, no. 4, pp. 922-924. PMid:17926367. http://dx.doi.org/10.1645/GE-1137R.1.

TKACH, V.V., KUZMIN, Y. and SNYDER, S.D., 2014. Molecular insight into systematics, host associations, life cyclesand geographic distribution of the nematode family Rhabdiasidae. International Journal for Parasitology, vol. 44, no. 5, pp. 273-284. PMid:24560917. http://dx.doi.org/10.1016/j.ijpara.2013.12.005.

TORRES, P. and PUGA, S., 1996. Occurrence of cystacanths of Centrorhynchus sp. (Acanthocephala: Centrorhynchidae) in toads of the genus Eupsophus in Chile. Memorias do Instituto Oswaldo Cruz, vol. 91, no. 6, pp. 717-719. PMid:9283651. http:// dx.doi.org/10.1590/S0074-02761996000600011.

VICENTE, J.J. and SANTOS, E., 1974. Sobre um novo nematódeo do gênero Physaloptera Rudolphi, 1819 parasito de cobra d'água (Nematoda, Spiruroidea). Atas da Sociedade de Biologia do Rio de Janeiro, vol. 17, no. 2, pp. 69-71.

VICENTE, J.J., RODRIGUES, H.O., GOMES, D.C. and PINTO, R.M., 1993. Nematóides do Brasil III. Nematóides de Répteis. Revista Brasileira de Zoologia, vol. 10, no. 1, pp. 19-168. http:// dx.doi.org/10.1590/S0101-81751993000100003.

VOLONTERIO, O., BALETTA, S. and MENEGHEL, M., 2006. A new genus and species of Opisthogonimid (Digenea) of Liophis anomalus (Serpentes: Colubridae) from Uruguay. The Journal of Parasitology, vol. 92, no. 5, pp. 1058-1063. PMid:17152951. http://dx.doi.org/10.1645/GE-820R.1. 